\title{
STUDI PERLAKUAN ALKALI TERHADAP SIFAT MEKANIK BAHAN KOMPOSIT BERPENGUAT SEKAM PADI
}

\author{
Sri Endah Susilowati \\ Fakultas Teknik, Universitas 17 Agustus 1945 Jakarta \\ sriendah.susilowati@yahoo.com
}

\begin{abstract}
Penggunaan serat alam mulai dilirik sebagai salah satu sumber material alternatif. Serat alam mudah ditemukan di lingkungan tempat tinggal kita dan merupakan energi terbarukan. Keunggulan utama penggunaan serat alam dibandingkan dengan serat sintetis yaitu serat alam dapat terurai oleh kondisi lingkungan (biodegradable), harganya murah dan mempunyai densitas yang rendah. Penggunaan serat alam sebagai bahan penguat dalam komposit masih memiliki kendala, yaitu ikatan yang dihasilkan antara serat dan matriks masih belum sempurna. Serat alam memiliki lapisan lignin (lapisan lilin) yang terdapat di seluruh permukaan serat. Lapisan lignin inilah yang mengakibatkan kurang baiknya ikatan antara serat dengan matriks. Karena itu dilakukanlah perlakuan untuk menghilangkan lapisan tersebut. Salah satu metoda yang digunakan adalah perlakuan alkalisasi, dimana serat direndam dalam larutan $\mathrm{NaOH}$.

Metode penelitian dilakukan dengan pengujian sifat mekanik (kekuatan bending, kekuatan tarik, SEM) pada komposit sekam padi dan matrik urea formaldehide dengan variasi perlakuan perbandingan sekam padi Vf $=30 \%, 40 \%, 50 \%$ dan $60 \%$ sedang urea formaldehide $\mathrm{Vm}=70 \%, 60 \%, 50 \%, 40 \%$ dan perlakuan alkalisasi pada sekam padi masing-masing direndam dalam larutan alkali selama 4 jam. Komposit yang akan digunakan dibuat dengan metoda cetak tekan dan dilakukan pengujian sifat mekanik. Sebagai parameter pengujian peralatan uji yang digunakan adalah uji bending dengan ASTM D790 - 02 dan uji tarik dengan ASTM D 638-02. Alat uji yang digunakan adalah Universal Testing Machine.
\end{abstract}

Kata kunci : sekam padi, urea formaldehyde, sifat mekanis

\section{PENDAHULUAN}

Komposit dari bahan serat (fibrous composite) terus diteliti dan dikembangkan guna menjadi bahan alternatif pengganti bahan logam, hal ini disebabkan sifat dari komposit serat yang kuat dan mempunyai berat yang lebih ringan dibandingkan dengan logam. Komposit merupakan perpaduan dari dua material atau lebih yang memiliki fasa yang berbeda menjadi suatu material baru yang memiliki properties lebih baik dari keduanya.

Sampai dengan saat ini, sebagian besar rakyat Indonesia masih berpenghasilan dari hasil pertanian. Khususnya hasil pertanian padi merupakan penghasilan utama sekaligus sebagai makanan pokok rakyat. Produksi padi yang besar juga akan diiringi dengan limbah sekam yang melimpah. Selama ini limbah sekam

Jurnal Kajian Teknik Mesin

Vol. 2 No. 1 April 2017 
padi tersebut belum digunakan secara maksimal, biasanya digunakan untuk pembakaran batu bata atau bahan bakar lain yang secara ekonomi kurang menghasilkan produk yang lebih berharga. Melihat potensi serta keunggulan limbah sekam padi yang begitu besar, maka diupayakan untuk mengoptimalkan pemanfaatan limbah sekam padi ini sebagai bahan dasar panel komposit.

Sekam padi adalah bagian terluar dari butir padi, yang merupakan hasil sampingan saat proses penggilingan padi dilakukan. Sekitar $20 \%$ dari bobot padi adalah sekam padi. Sekam padi mempunyai beberapa keunggulan seperti kemampuan menahan kelembaban, tidak mudah terbakar, tidak mudah berjamur, tidak berbau dan lain-lain. Pada penggilingan padi, besar sekam belum dimanfaatkan dan pengusaha pengggilingan mengalami kesulitan dalam pemusnahannya. Pemanfaatan limbah sekam masih berpeluang besar untuk digunakan sebagai bahan rekayasa. Dengan menambahkan perekat yang murah, sekam padi ini berpotensi untuk direkayasa menjadi produk core fleksibel untuk pembuatan panel komposit sandwich.

Bahan urea formaldehide (UF) merupakan jenis resin yang tepat sebagai perekat pembuatan core limbah sekam padi karena harganya sangat murah. Bahan ini mudah diperoleh karena telah diproduksi dan banyak di pasaran. Bahan UF ini sangat cocok untuk digunakan sebagai perekat produk core karena komponen core di dalam struktur panel komposit sandwich terkena pembebanan yang rendah. Oleh karena itu, untuk menekan biaya produk panel sandwich perlu dilakukan pemilihan bahan yang murah pada komponen yang terkena tegangan kecil, seperti bagian core yang berada di bagian tengah panel.

Perlakuan alkalisasi bertujuan untuk membuang lapisan lilin yang menyelimuti serat alam sebelum dijadikan material komposit. Perlakuan alkalisasi dilakukan dengan cara perendaman serat didalam larutan $\mathrm{NaOH}$ dengan variasi lama perendaman yaitu 4 jam , 6 jam, 8 jam dan 10 jam. Kemudian dilakukan pengujian tarik dan bending terhadap komposit sehingga didapatkan persentase optimum dari perlakuan alkalisasi terhadap kekuatan mekanik komposit sekam padi. Volume fraksi sekam padi yang digunakan untuk setiap sampel adalah $40 \%$ dan $50 \%$ dengan metoda pembuatan adalah metoda cetak tekan.

Dari uraian di atas maka penelitian ini dilakukan untuk mendapatkan data 
tentang kemampuan fisis dan mekanis berupa kekuatan bending dan kekuatan tarik dari sekam padi dengan perlakuan perendaman $\mathrm{NaOH}$ dan menggunakan matrik urea formaldehide dengan proses hot press serta dibuat dengan metode hand lay up. Sehingga dari penelitian ini diharapkan sekam padi dapat bermanfaat dalam bidang industri manufaktur saat ini.

\subsection{Perumusan Masalah}

Fokus dalam penelitian ini didasarkan pada suatu rumusan masalah sebagai berikut:

1. Bagaimana pengaruh sifat-sifat mekanik pada variasi fraksi volume sekam padi dari komposit berpenguat sekam padi dan bermatrik urea formaldehide dengan proses hot press pada suhu $60^{\circ} \mathrm{C}$ selama 24 jam.

2. Bagaimana pengaruh sifat-sifat mekanik pada perlakuan alkali dengan perendaman selama 4 jam dengan variasi fraksi volume dari komposit berpenguat sekam padi dan bermatrik urea formaldehide dengan proses hot press pada suhu $60^{\circ} \mathrm{C}$ selama 24 jam.

3. Bagaimana struktur bahan pada pengujian sifat mekanik dengan Foto Makro.

Jurnal Kajian Teknik Mesin

Vol. 2 No. 1 April 2017

\subsection{Tujuan Penelitian}

Tujuan dari penelitian yang dilakukan ini adalah:

1. Mengetahui pengaruh kekuatan bending pada variasi fraksi volume sekam padi dan perlakuan alkalisasi dari komposit berpenguat sekam padi dan bermatrik urea formaldehide dengan proses hot press pada suhu $60^{\circ} \mathrm{C}$ selama 24 jam.

2. Mengetahui pengaruh kekuatan tarik pada variasi fraksi volume sekam padi dan perlakuan alkalisasi dari komposit berpenguat sekam padi dan bermatrik urea formaldehide dengan proses hot press pada suhu $60^{\circ} \mathrm{C}$ selama 24 jam.

3. Mengetahui hasil struktur pada pengujian sifat-sifat mekanik dengan Foto Makro.

\subsection{Manfaat Penelitia}

Hasil Penelitian ini diharapkan dapat memberi manfaat, diantaranya:

1. Dapat memaksimalkan pemanfaatan limbah pertanian sebagai bahan material komposit.

2. Membuat suatu produk material komposit yang murah dan kuat dalam penggunaannya

3. Memberikan kontribusi bagi industri manufaktur dan kontruksi dalam pembuatan material komposit. 


\section{KAJIAN PUSTAKA}

Shobari Akhmad Nadji (2014), telah meneliti kekuatan tarik dan kekuatan lentur komposit epoksi berpengisi serat ampas tebu dengan variasi perlakuan alkali $0 \%, 1 \%, 2 \%$ dan $3 \%$ dengan variasi fraksi volume ampas tebu $0 \%, 30 \%, 40 \%$ dan $50 \%$ menghasilkan nilai kekuatan tarik maksimum diperoleh pada komposisi Epoksi : ampas tebu 70:30 dengan konsentrasi $\mathrm{NaOH} 2 \%$ sebesar 23,26 $\mathrm{MPa}$ sedang nilai kekuatan lentur maksimum diperoleh pada komposisi epoksi : ampas tebu 70 : 30 dengan konsentrasi $\mathrm{NaOH} 2 \%$ sebesar 50,17 MPa.

Irwanto dkk (2014) meneliti pengaruh alkalisasi dengan $\mathrm{NaOH}$ melalui perendaman selama 2 jam pada struktur komposit berpenguat serat alam (serat kelapa, serat pisang dan serat padi) terhadap kekuatan tarik, dimana nilai tertinggi pengujian kekuatan tarik diperoleh pada komposit dengan serat kelapa sebesar $60,18 \mathrm{~kg} / \mathrm{cm}^{2}$, sedangkan untuk serat padi sebesar $34,91 \mathrm{~kg} / \mathrm{cm}^{2}$ dan serat pelepah pisang sebesar $50,07 \mathrm{~kg} / \mathrm{cm}^{2}$.

Sony (2005), meneliti kekuatan bending dan tarik komposit berpenguat serbuk tempurung kelapa dan abu sekam padi yang dikombinasikan dengan epoxy menghasilkan data sebagai berikut, untuk komposit serbuk tempurung kelapa mempunyai kekuatan tarik $21.055 \mathrm{MPa}$, dan kekuatan bending $31.716 \mathrm{MPa}$. Sedangkan komposit serbuk abu sekam padi mempunyai kekuatan tarik 18.836 $\mathrm{MPa}$, dan kekuatan bending $31.716 \mathrm{MPa}$.

Sandi Eko Prasetyo (2015) telah meneliti pengaruh waktu rendam bahan kimia $\mathrm{NaOH}$ terhadap sifat fisis dan mekanis komposit serat bulu kambing sebagai fiber dengan matrik polyester, dengan variasi waktu rendam di dalam larutan $\mathrm{NaOH}$ 5\% selama 0, 30, 60, 90 dan 120 menit diperoleh hasil yang maksimal pada perendaman serat bulu kambing selama 60 menit yaitu sebesar 19,254 $\mathrm{N} / \mathrm{mm}^{2}$.

Roseno (2003) menggunakan analisa struktur mikro serat, kandungan selulosa/lignin, serta orientasi serat alam untuk membuat suatu model mekanis serat alam. Perhitungan dengan pendekatan mikromekanika telah dilakukan dengan memperhitungkan dinding sel serat alam sebagai komposit berpenguat serat diskontinyu,dan mengasumsikan ikatan antar serat dan matriknya dalam ikatan sempurna. Modulus Young serat alam diprediksi dengan menggunakan persamaan Tsai-Halpin dan penerapan kaidah rule of mixtures dengan sedikit modifikasi dalam formulanya yang 
memperhitungkan faktor porisitas. Teknik analisa kekuatan serat ini kemudian dapat digunakan untuk menghitung karakteristik mekanik (kekuatan dan kekakuan) komposit berpenguat serat. Faktor efisiensi digunakan pada perhitungan kekuatan komposit berpenguat serat pendek/diskon tinyu.

\section{METODE PENELITIAN}

\subsection{Diagram Alir Penelitian}

Jurnal Kajian Teknik Mesin

Vol. 2 No. 1 April 2017

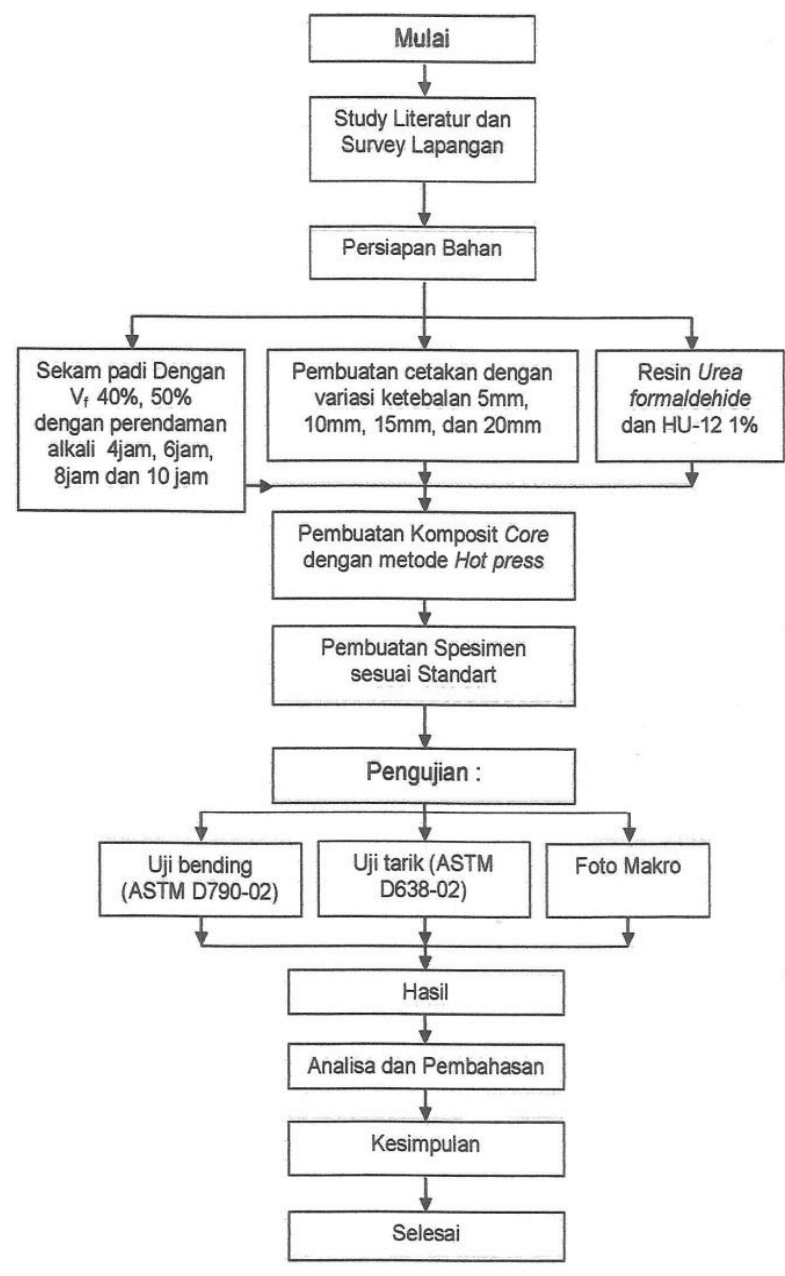

Gambar 3.1 Diagram Alir Penelitian

\subsection{Lokasi Penelitian}

Tempat penelitian meliputi laboratorium

Teknik Mesin Universitas 17 Agustus 1945 Jakarta dan Laboratorium PUSPIPTEK Serpong.

\subsection{Bahan Penelitian}

Bahan yang digunakan dalam penelitian ini adalah sebagai berikut:

1. Sekam padi

Sekam padi dicuci dahulu untuk menghilangkan kotoran yang ada pada sekam, kemudian direndam dengan 
larutan $\mathrm{NaOH}$ selama 4 jam, kemudian

dijemur. Setelah melalui proses penjemuran sekam diketahui kadar air menjadi $8-10 \%$.

2. Urea Formaldehide

Jenis Urea Formaldehide yang digunakan adalah tipe UF 181 dan hardener HU-12, Resin ini berbentuk cair berwarna putih dan pada suhu kamar akan mengeras dalam waktu sekitar 30 menit dengan menggunakan katalis/initiator.

\subsection{Alat Penelitian}

Alat-alat yang digunakan pada penelitian ini yaitu :

1. Alat Uji Kadar Air, dipergunakan untuk mengukur kadar air sekam padi, Cara menggunakannya adalah dengan menempelkan bahan yang akan diuji kadar airnya pada indikator dan nilai kadar air akan muncul dengan ketentuan kadar air 10\%.

2. Timbangan digital, digunakan untuk menimbang sekam padi dan urea formaldehide adalah timbangan digital.

3. Cetakan Benda Uji, terbuat dari kaca bening dengan ketebalan $5 \mathrm{~mm}$, $10 \mathrm{~mm}, 15 \mathrm{~mm}$, dan $20 \mathrm{~mm}$.

4. Alat Pengepres Cetakan.
Alat press mold ini digunakan untuk membantu proses pembuatan spesimen benda uji komposit.

5. Alat Bantu lain, meliputi : sendok, cutter, kit mobil, pisau, spidol, gergaji besi, obeng, dan gelas ukur.

6. Alat Uji Sifat Mekanik

Universal Testing Machine, alat ini digunakan untuk melakukan uji bending komposit

7. Alat Uji Tarik, dengan menggunakan Universal Testing Machine, alat uji ini digunakan untuk melakukan pengujian tarik komposit.

\subsection{Variabel Penelitian}

1. Variabel Bebas

a. Sekam padi dengan $\mathrm{V}_{\mathrm{f}} 30 \%, 40 \%$, $50 \%$ dan $60 \%$.

b. Pembuatan cetakan dengan variasi ketebalan $5 \mathrm{~mm}, 10 \mathrm{~mm}, 15 \mathrm{~mm}$, dan $20 \mathrm{~mm}$

c. Resin Urea formaldehide dan HU12 sebesar $1 \%$

d. Perlakuan alkali dengan perendaman selama 4 jam.

2. Variabel Terikat

a. Uji Bending (ASTM D79002)

b. Uji Tarik (ASTM D638-02)

c. Foto Makro

\subsection{Rancangan Penelitian}




\subsubsection{Persiapan bahan}

Mengumpulkan semua bahanbahan yang akan digunakan dalam proses pembuatan komposit core. Diantaranya yaitu sekam padi dan urea formaldehyde beserta hardener dan larutan $\mathrm{NaOH}$ untuk perlakuan Alkali.

Proses pembuatan komposit sekam padi dengan matrik urea formaldehide adalah sebagai berikut:

1. Penyiapan sekam padi, untuk sekam padi dicuci dahulu, kemudian direndam dalam larutan $\mathrm{NaOH}$ dengan selama 4jam lalu dikeringkan sampai kadar air mencapai 10\%.

2. Setelah sekam padi kering kemudian dilakukan proses pemisahan antara tangkai dan butir sekam padi.

3. Pembuatan cetakan. Cetakan benda uji terbuat dari kaca setebal $5 \mathrm{~mm}$. Ukuran untuk masing-masing jenis pengujian adalah sebagai berikut :

Tabel 3.1. Dimensi benda uji untuk pengujian bending

\begin{tabular}{|c|c|c|}
\hline $\begin{array}{c}\text { Tebal } \\
\text { komposit }\end{array}$ & $\begin{array}{c}\text { Ukuran } \\
\text { cetakan } \\
(\mathrm{mm})\end{array}$ & $\begin{array}{c}\text { Daerah } \\
\text { pencetakan } \\
(\mathrm{mm})\end{array}$ \\
\hline $5 \mathrm{~mm}$ & $120 \times 100 \times 10$ & $100 \times 80 \times 5$ \\
\hline $10 \mathrm{~mm}$ & $120 \times 100 \times 15$ & $100 \times 80 \times 10$ \\
\hline $15 \mathrm{~mm}$ & $120 \times 100 \times 20$ & $100 \times 80 \times 15$ \\
\hline $20 \mathrm{~mm}$ & $120 \times 100 \times 25$ & $100 \times 80 \times 20$ \\
\hline
\end{tabular}

Tabel 3.2. Dimensi benda uji untuk pengujian tarik

\begin{tabular}{|c|c|c|}
\hline $\begin{array}{c}\text { Tebal } \\
\text { komposit }\end{array}$ & $\begin{array}{c}\text { Ukuran } \\
\text { cetakan } \\
(\mathrm{mm})\end{array}$ & $\begin{array}{c}\text { Daerah } \\
\text { pencetakan } \\
(\mathrm{mm})\end{array}$ \\
\hline $5 \mathrm{~mm}$ & $185 \times 120 \times 10$ & $165 \times 100 \times 5$ \\
\hline $10 \mathrm{~mm}$ & $185 \times 120 \times 15$ & $165 \times 100 \times 10$ \\
\hline $15 \mathrm{~mm}$ & $185 \times 120 \times 20$ & $165 \times 100 \times 15$ \\
\hline $20 \mathrm{~mm}$ & $185 \times 120 \times 25$ & $165 \times 100 \times 20$ \\
\hline
\end{tabular}

4. Pengolesan wax mold release atau kit motor pada cetakan untuk memudahkan pengambilan benda uji dari cetakan setelah mengalami proses pengeringan.

5. Resin urea formaldehide dicampur dengan hardener untuk membantu proses pengeringan. hardener yang digunakan sebanyak $1 \%$ dari banyaknya resin urea formaldehide yang digunakan.

6. Penuangan campuran antara sekam padi dan urea formaldehide kedalam gelas ukur dan dicampur menjadi adonan, kemudian dituangkan kedalam cetakan sambil dipukul-pukul dengan sendok biar lebih merata dan padat. Kemudian ditutup dengan kaca dan ditekan dengan dengan alat penekan.

7. Penutupan dengan menggunakan kaca yang bertujuan agar void yang kelihatan dapat diminimalkan jumlahnya yang kemudian dilakukan pengepresan dengan menggunakan alat pengepres. 
8. Proses pencetakan ini menggunakan proses hot press pada suhu $60{ }^{\circ} \mathrm{C}$ selama 24 jam.

9. Proses pengambilan komposit dari cetakan yaitu menggunakan pisau ataupun cutter.

10. Benda uji komposit siap untuk dipotong menjadi spesimen benda uji.

\subsubsection{Pembuatan Spesimen Benda Uji}

Setelah proses penyetakan selesai maka spesimen dipotong menurut ukuran standar tarik dan bending yang digunakan. Pada proses pembuatan spesimen uji. Spesimen yang akan diuji jumlahnya yaitu 3 spesimen tiap variasi volume dan tebal. Untuk uji tarik ukuran spesimennya yaitu lebar $19 \mathrm{~mm}$, tebal 5, 10, 15, $20 \mathrm{~mm}$ dan panjang spesimennya sama $165 \mathrm{~mm}$. Sedangkan ukuran spesimen bendingnya yaitu panjang $96 \mathrm{~mm}$, lebar $12 \mathrm{~mm}$ dan tinggi variasi yaitu 5, 10, 15, $20 \mathrm{~mm}$.

\subsubsection{Pengujian Komposit}

Pengujian yang dilakukan pada penelitian ini antara lain pengujian bending, pengujian tarik, foto makro.

1. Pengujian bending.

Material komposit mempunyai sifat tekan yang lebih baik dibanding sifat tariknya. Kekuatan tarik di pengaruhi oleh ikatan molekul material penyusunnya.
Pada pengujian bending ini bertujuan untuk mengetahui besarnya kekuatan lentur dari material komposit. Pengujian dilakukan dengan jalan memberi beban lentur secara perlahan-lahan sampai spesimen mencapai titik lelah. Pada perlakuan uji bending bagian atas spesimen mengalami proses penekanan dan bagian bawah mengalami proses tarik sehingga akibatnya spesimen mengalami patah bagian bawah karena tidak mampu menahan tegangan tarik. Spesimen uji bending dibuat sesuai standar ASTM D790 -02 .

Langkah-langkah pengujian bending yaitu:

a. Mempersiapkan benda uji.

b. Menentukan titik tumpuan dan titik tengah benda uji dengan memberi tanda garis.

c. Menentukan besarnya beban yang digunakan.

d. Meletakkan spesimen pada meja mesin pengujian bending dengan jarak tumpuan dan titik tengah yang telah ditentukan.

e. Putar handle sampai beban menyentuh benda uji dan manometer indikator menunjukkan angka nol.

f. Tentukan putaran jarum penentu waktu untuk pencatatan beban selanjutnya. 
g. Catat hasil pengujian bending setiap putaran yang telah ditentukan.

h. Menentukan harga bending.

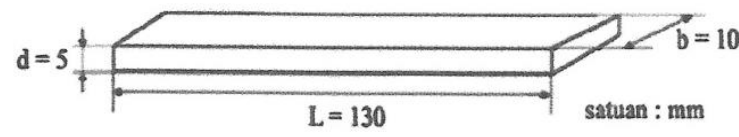

Gambar 3.2. Dimensi benda pengujian bending (Standar ASTM D 790-02)

\section{Pengujian tarik.}

Pengujian tarik dilakukan untuk mengetahui besarnya kekuatan tarik dari bahan komposit. Pengujian dilakukan dengan mesin uji "Universal Testing Machine” buatan jepang. Hasil pengujian dengan mesin ini lebih akurat karena melalui grafik tegangan-regangan: Spesimen pengujian tarik di bentuk menurut standar ASTM D 638-02 yang ditunjukkan pada gambar berikut:

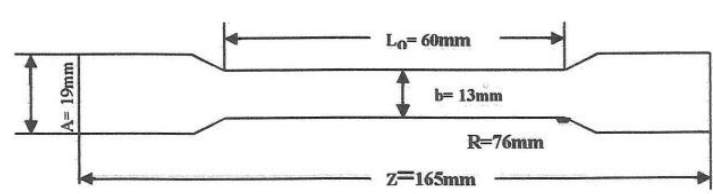

Gambar 3.3. Dimensi benda pengujian tarik (Standar ASTM D 638-02)

Keterangan :

Lo : Panjang awal(mm)

b : Lebar (mm)

Z : Panjang total spesimen(mm)

$d \quad$ :Tebal (mm)

$A \quad$ : Lebar spesimen(mm)

Langkah-langkah pengujian tarik: a. Mesin uji tarik harus menunjukkan indikator nol.

b. Memasang batang uji tarik pada alat dengan cara dijepit tepat pada pegangan spesimen uji tersebut.

c. Mengeset program di komputer untuk menjalankan alat uji tarik tersebut.

d. Mengeprint hasil uji tarik yang telah keluar data-datanya didalam komputer

\section{Foto Patahan Makro}

Pengambilan foto makro bertujuan untuk mengetahui jenis/bentuk patahan dan pola kegagalan yang terjadi pada spesimen komposit akibat pengujian bending dan tarik. Objek yang diambil dari penampang patahan dan dari samping untuk pengujian tarik sedangkan untuk bending diambil dari samping benda uji.

\section{HASIL DAN PEMBAHASAN}

\subsection{Hasil Pengujian Bending}

Dari pengujian komposit sekam padi dengan perlakuan alkali selama 4 jam diperoleh hasil di bawah ini :

Kekuatan bending rata-rata tertinggi diperoleh pada komposit dengan fraksi volume sekam padi $40 \%$ dengan tebal spesimen $5 \mathrm{~mm}$ sebesar sebesar 3,1123 MPa dan nilai terendah adalah sampel dengan fraksi volume $60 \%$ dan 
ketebalan $15 \mathrm{~mm}$ sebesar $1,3750 \mathrm{MPa}$ (ketebalan 15mm dan fraksi volume 60\%).

Tabel 4.1. Hasil Perhitungan Rata-rata Kekuatan Bending

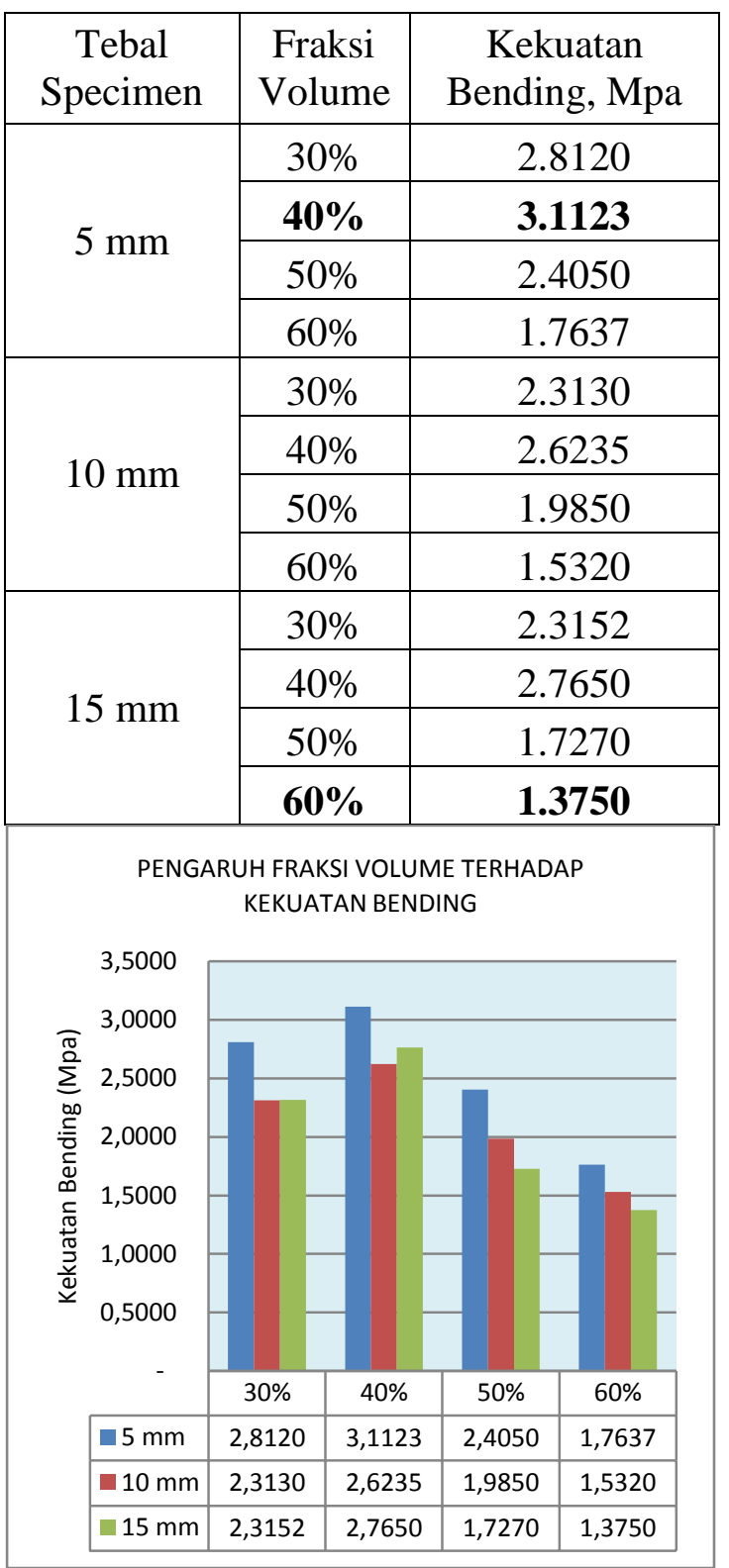

Gambar 4.1. Pengaruh Fraksi Volume Terhadap Kekuatan Bending

Semakin besar peningkatan fraksi volume jerami padi sampai $40 \%$ akan meningkatkan kekuatan bending komposit, tetapi peningkatan selanjutnya fraksi volume ( $50 \%$ dan $60 \%$ ) akan menurunkan kekuatan bending. Hal ini disebabkan karena spesimen cenderung menjadi rapuh.

Nilai kekuatan Bending spesimen komposit jerami padi dengan fraksi volume $30 \%$ dan tebal $5 \mathrm{~mm}$ sebesar 2,8120 MPa dan untuk fraksi volume $40 \%$ nilai Bending mencapai optimum 3,1123 $\mathrm{MPa}$ untuk selanjutnya mengalami penurunan berturut turut dengan fraksi volume $50 \%$, 60\% sebesar 2,4050 $\mathrm{MPa}$, dan terendah $1,3750 \mathrm{MPa}$

Nilai tertinggi Uji Bending berdasarkan data diperoleh pada komposit dengan fraksi volume $40 \%$ sekam padi dan 60\% Resin, dikarenakan pada perbandingan ini dapat bercampur secara sempurna terlihat dari hasil pengujian bending yang dilakukan bahwa rata rata nilai tegangan bending pada komposit berkisar 3,1123 MPa.

\subsection{Hasil Pengujian Tarik}

Untuk pengujian kuat tarik diperoleh nilai optimal pada sampel dengan fraksi volume $40 \%$ dan ketebalan $5 \mathrm{~mm}$ sebesar 0,4220 MPa sedang nilai terendah adalah sampel dengan fraksi volume $60 \%$ dan ketebalan $15 \mathrm{~mm}$ yaitu sebesar 0,1452 MPa. 
Tabel 4.2. Hasil Perhitungan Rata-rata Kekuatan Tarik

\begin{tabular}{|c|c|c|}
\hline $\begin{array}{c}\text { Tebal } \\
\text { Specimen }\end{array}$ & $\begin{array}{c}\text { Fraksi } \\
\text { Volume }\end{array}$ & $\begin{array}{c}\text { Kekuatan } \\
\text { Tarik, Mpa }\end{array}$ \\
\hline \multirow{4}{*}{$5 \mathrm{~mm}$} & $30 \%$ & 0.3856 \\
\cline { 2 - 3 } & $\mathbf{4 0 \%}$ & $\mathbf{0 . 4 2 2 0}$ \\
\cline { 2 - 3 } & $50 \%$ & 0.3335 \\
\cline { 2 - 3 } & $60 \%$ & 0.2861 \\
\hline \multirow{4}{*}{$10 \mathrm{~mm}$} & $30 \%$ & 0.2875 \\
\cline { 2 - 3 } & $40 \%$ & 0.3310 \\
\cline { 2 - 3 } & $50 \%$ & 0.2900 \\
\cline { 2 - 3 } $15 \mathrm{~mm}$ & $60 \%$ & 0.2100 \\
\hline \multirow{5}{*}{} & $30 \%$ & 0.2102 \\
\cline { 2 - 3 } & $40 \%$ & 0.2250 \\
\cline { 2 - 3 } & $50 \%$ & 0.1750 \\
\hline
\end{tabular}

Sama seperti Uji Bending, semakin besar peningkatan fraksi volume jerami padi sampai 40\% akan meningkatkan kekuatan tarik komposit, tetapi peningkatan selanjutnya fraksi volume ( $50 \%$ dan $60 \%$ ) akan menurunkan nilai Kuat Tarik.

Nilai besarnya kekuatan Tarik spesimen komposit jerami padi dengan fraksi volume $30 \%$ dan tebal $5 \mathrm{~mm}$ sebesar 0,3856 MPa dan untuk fraksi volume $40 \%$ nilai Bending mencapai optimum sebesar 0,4220 MPa untuk selanjutnya mengalami penurunan berturut turut dengan fraksi volume 50\%, 60\% sebesar 0,3335 Mpa dan terendah 0,1452 Mpa (ketebalan $15 \mathrm{~mm}$ dan fraksi volume $60 \%$ ).

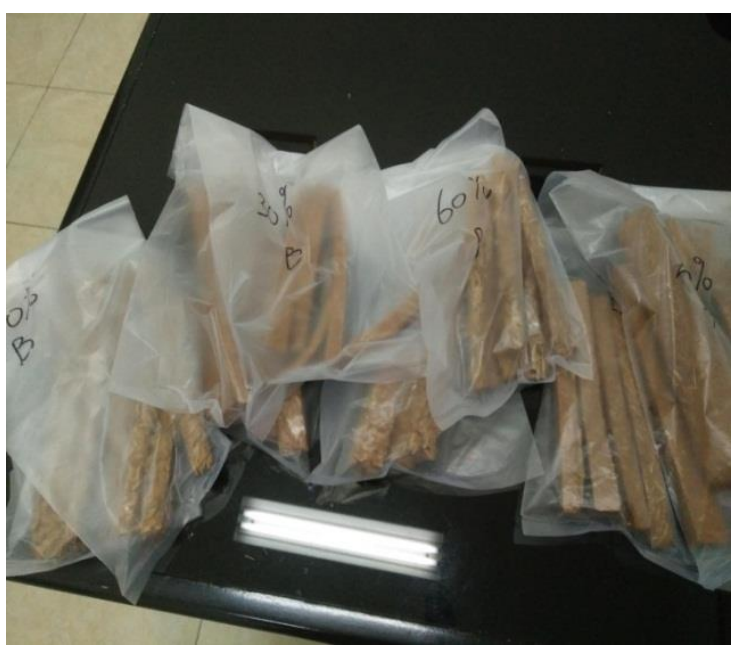

Gambar 4.3. Specimen dengan Variasi Perlakuan Fraksi Volume 


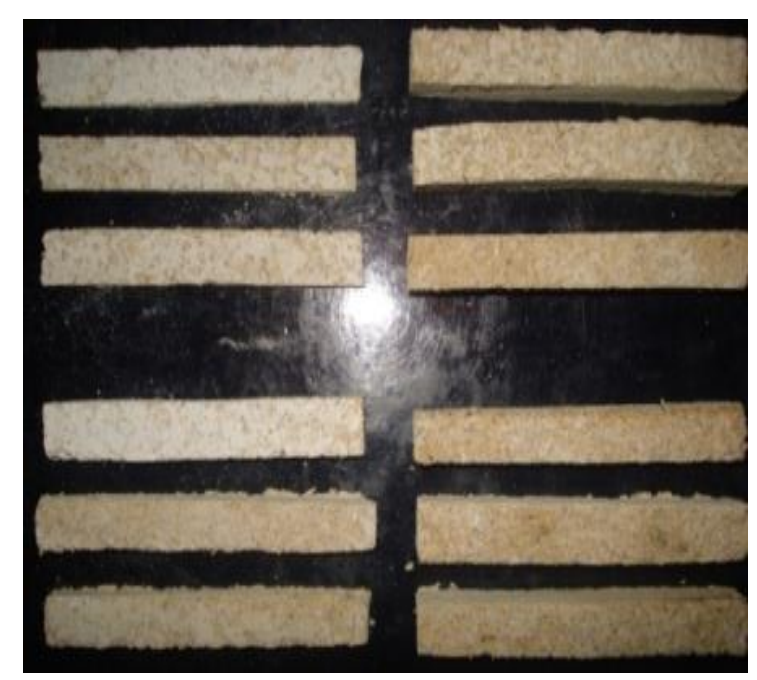

Gambar. 4.3. Specimen Benda Uji

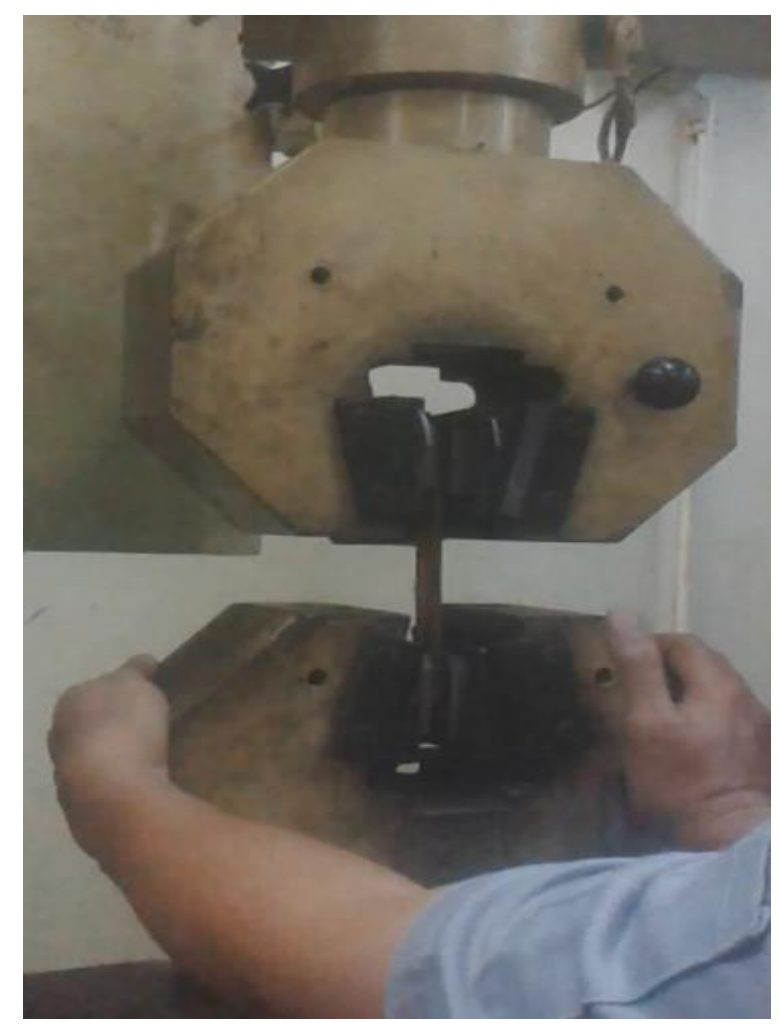

Gambar 4.4 Pengujian tarik

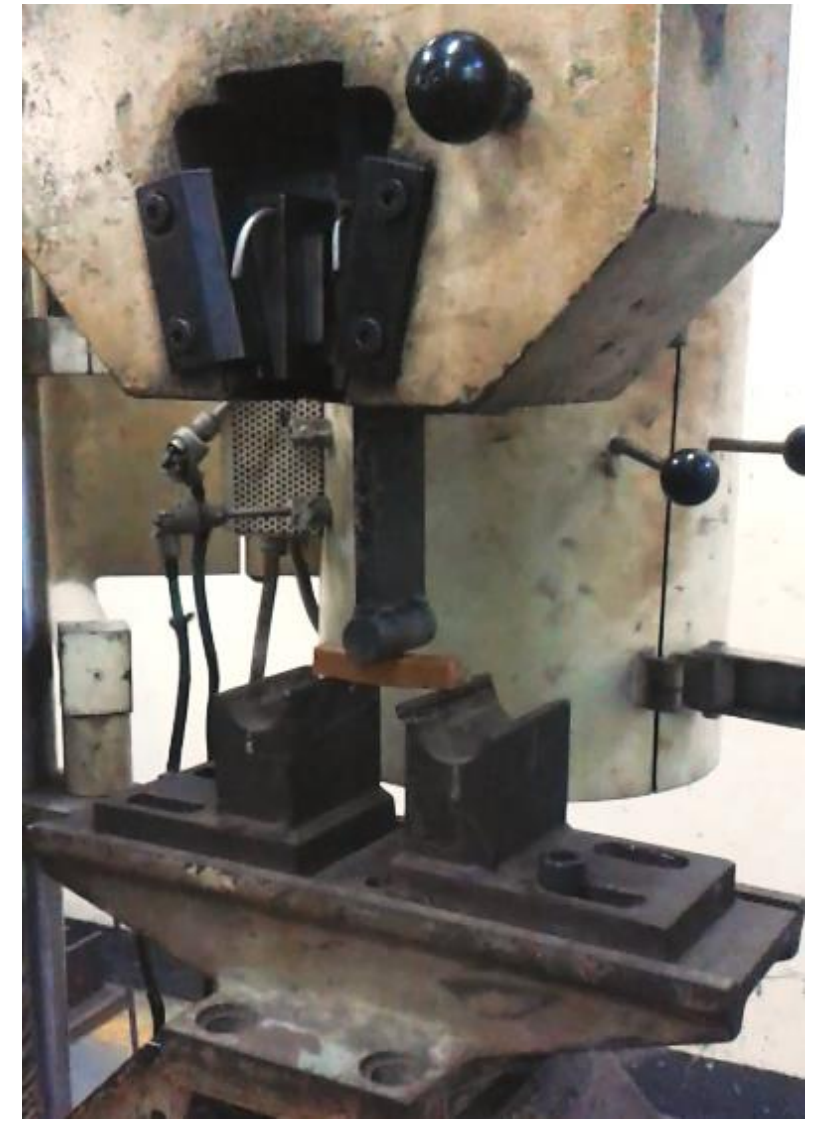

Gambar 4.5. Pengujian bending

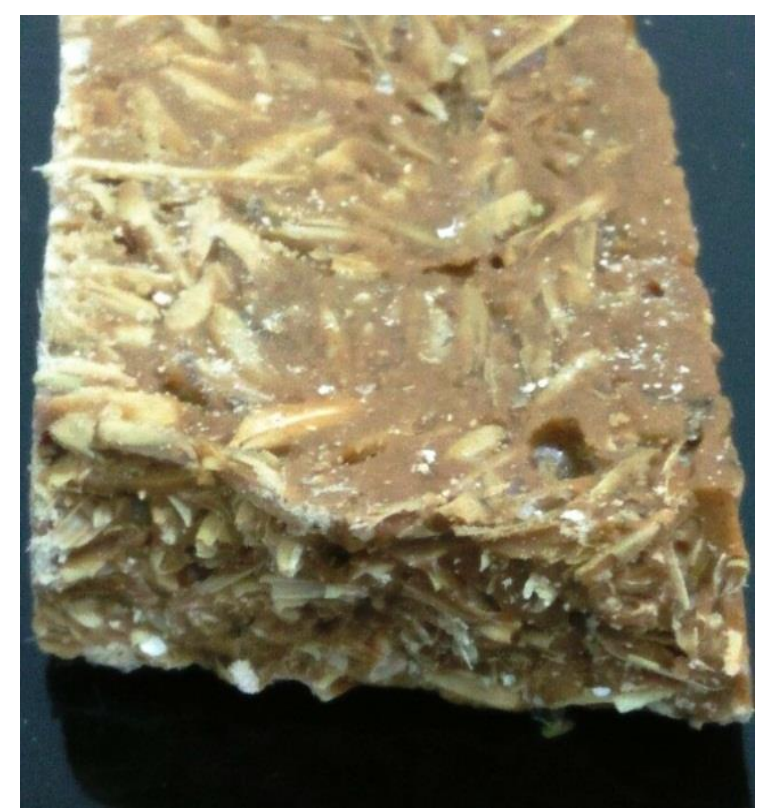

Gambar 4.6. Foto patahan makro 


\section{KESIMPULAN DAN SARAN}

\section{Kesimpulan}

1. Kekuatan bending rata-rata tertinggi diperoleh pada komposit dengan fraksi volume sekam padi $40 \%$ dengan tebal spesimen $5 \mathrm{~mm}$ sebesar sebesar 3,1123 $\mathrm{MPa}$ dan nilai terendah adalah sampel dengan fraksi volume $60 \%$ dan ketebalan $15 \mathrm{~mm}$ sebesar 1,3750 MPa.

2. Untuk pengujian kuat tarik diperoleh nilai optimal pada sampel dengan fraksi volume $40 \%$ dan ketebalan 5mm sebesar 0,4220 MPa sedang nilai terendah adalah sampel dengan fraksi volume $70 \%$ dan ketebalan $15 \mathrm{~mm}$ yaitu sebesar 0,1452 MPa.

\section{Saran}

Penelitian ini merupakan penelitian pendahuluan, sehingga perlu dilakukan penelitian lanjutan dengan memanfaatkan berbagai serat alam yang lain. Penggunaan serat alam sebagai bahan penguat dalam komposit masih memiliki kendala, yaitu ikatan yang dihasilkan antara serat dan matriks masih belum sempurna. Serat alam memiliki lapisan lignin (lapisan lilin) yang terdapat di seluruh permukaan serat. Lapisan lignin inilah yang mengakibatkan kurang baiknya ikatan antara serat dengan matriks. Karena itu perlu dilakukanlah penelitian dengan perlakuan untuk menghilangkan lapisan tersebut , diantaranya adalah perlakuan alkalisasi, dimana serat direndam dalam larutan $\mathrm{NaOH}$ dengan variasi konsentrasi $\mathrm{NaOH}$ yang berbeda beda dan variasi lamanya perendaman yang berbeda pula.

\section{DAFTAR PUSTAKA}

ASTM D 638-02, 2002, Standard Test Method for Tensile Properties of Plastics, An American National Standard.

ASTM D 790-02, 2002, Standard Test Method for Flexural Properties of Unreinforce and Reinforced Plastics and Electrical Insulating Materials, An American National Standard.

Callister, W. D., 2007, Material Science and Enginering, An Introduction 7ed, Department of Metallurgical Enginering The University of Utah, John Willey and Sons, Inc.

Gibson, Ronald F. 1994.Principle Of Composite Material Mechanics. New York : Mc Graw Hill,Inc.

Harper, A. C., 1996, Handbook of Plastics, Elastomers and Composites, $\mathrm{Mc}$ Graw Hill Componies, Inc.

Irwanto, S.M.B.,2014, Analisis Kekuatan Tarik dan Struktur Komposit Berpenguat Serat Alam Sebagai bahan Alternative Pengganti Serat Kaca Untuk Pembuatan Dashboard. Jurnal Momentum. Vol 10, No.2 Univ. Wahid Hasyim. Semarang. 
Jones, M. R., 1975, Mechanics of Composite Material, Mc Graww Hill Kogakusha, Ltd..

Lukkasen, D. and Meidell, A., 2003, Advance Materials and Structures and their Fabrication Processes, Third edition, Narvik University College, HiN.

Mueler, Dieter H. October 2003. New Discovery in the Properties of Composites Reinforced with Natural Fibers. JOURNAL OF INDUSTRIAL TEXTILES, Vol. 33, No. 2. Sage Publications.

Roseno, Seto. 2003. Karakteristik dan Model Mekanis Material Komposit Berpenguat Serat Alam. Jakarta: BPPT.

Shackelford, James, F., 1992, Introduction to Material Science for Enginering, London Prentice Hall International, Inc.

Smith, F. W., Hashemi, J., 2006, Foundation of Materials Science and Enginering, Mc Graw Hill Companies, Inc.

Sony. 2005., Kekuatan Bending dan Tarik Komposit Berpenguat Serbuk Tempurung Kelapa dan Abu Sekam Padi yang Dikombinasikan dengan Epoxy. Tugas Akhir, Teknik Mesin UMS, Surakarta.

Sandi Eko. 2015. Pengaruh Waktu Rendaman Bahan Kimia $\mathrm{NaOH}$ Terhadap Sifat Fisis dan Mekanis Komposit Serat Bulu Kambing Sebagai Fiber Dengan Matrik Polyester. Tugas Akhir, Teknik Mesin, UMS. Surakarta.

Shabiri, A. 2014. Pengaruh Perlakuan Alkali $(\mathrm{NaOH})$ Terhadap Kekuatan

Jurnal Kajian Teknik Mesin

Vol. 2 No. 1 April 2017
Mekanik Komposit Epoksi Berpengisi Serat Ampas Tebu. Tugas Akhir, Teknik Kimia. Universitas Sumatera Utara. 